This item was submitted to Loughborough's Research Repository by the author.

Items in Figshare are protected by copyright, with all rights reserved, unless otherwise indicated.

\title{
Living in diversity: going beyond the local/national divide
}

PLEASE CITE THE PUBLISHED VERSION

https://doi.org/10.1016/j.polgeo.2017.12.001

PUBLISHER

Elsevier

VERSION

AM (Accepted Manuscript)

PUBLISHER STATEMENT

This paper was accepted for publication in the journal Dalton Transactions and the definitive published version is available at https://doi.org/10.1016/j.polgeo.2017.12.001

\section{LICENCE}

CC BY-NC-ND 4.0

\section{REPOSITORY RECORD}

Antonsich, Marco. 2019. "Living in Diversity: Going Beyond the Local/national Divide". figshare.

https://hdl.handle.net/2134/27695. 
Forthcoming in Political Geography (2018) - accepted version

\section{Living in diversity: going beyond the local/national divide}

Dr Marco Antonsich

Department of Geography

Loughborough University

Loughborough, Leicestershire

LE1 1 3TU, UK

\section{M.Antonsich@1boro.ac.uk}

Abstract: As contemporary societies are undergoing a demographic change, spurred in great part by international immigration, living in diversity continues to remain a topical issue. Moving away from the nation, considered as a site of discrimination and exclusion, geographers and social scientist more broadly have focused on alternative socio-spatial formations. Over the last two decades or so, the local place, particularly the city or the neighbourhood within the city, has attracted considerable attention. Imbued with transnational and cosmopolitan traits, these local places have been narrated as progressive and empowering in contrast to a nation perceived as to embodying opposite dimensions. The present study critically interrogates this local/national divide. Drawing on narratives of Italians with foreign background talking and writing about their individual experiences of living and growing up in Italy, the article offers empirical evidence which challenges the local/national divide in two ways. First, participants blurred the distinction between these two scales, as identification and attachment to local places were narrated by also mobilizing national markers. Second, the sense of local rootedness of the participants was not cast against the nation, but it was strategically deployed to claim a place in the nation. These findings invite scholars to explore the different ways in which the nation intervenes in shaping life in diversity, beyond the dominant narrative of the local/national divide.

\section{Introduction}

Nation and ethno-cultural, racial and religious diversity (henceforth, abbreviated as diversity only) are often cast in opposition, both in the political discourse and in the academic debate (Antonsich and Matejskova 2015a). ${ }^{1}$ Politically, the present surge of populist nationalism in the US and in some European countries can be read as the latest manifestation of large 
portions of national electorates increasingly uncomfortable with the demographic transformation of 'their' nations brought about by international immigration (Inglehart and Norris 2016, Beauchamp 2017). In this context, demands by the white majority to retain a privileged entitlement to the national territory, culture and resources have also been voiced, linking the surge of populist nationalism to racialized conceptions of nation (Goodhart 2017, Kaufmann 2017). From this perspective, nations appear as closed and inward-looking collectives, where diversity, particularly when bears visible Muslim traits, becomes a source of concern (Brubaker 2017).

Maybe more conspicuous than in the past, these public attitudes and the political rhetoric which accompanies them are nevertheless not a new phenomenon, as studies based on past opinion surveys clearly reveal (Hochschild and Lang 2011, Simon and Sikich 2007, McLaren 2003, Shapiro 1997, Sides and Citrin 2007, Bail 2008). One could also point to the fact that, historically, the very process of nationalization of territories has often been read as either a process of eradication of pre-existing diversity in the form of local traditions and identities (Gellner 1983, Weber 1976 ) or a process of absorption of these local differences into a national whole (Applegate, 1990; Kaufmann, 2017). Thus, it is not surprising that many scholars working on diversity-related issues have moved the focus of their research away from the nation, in search of alternative socio-spatial registers where diversity might be more fully embraced and lived.

Starting in the early 1990s, transnationalism and cosmopolitanism have emerged as the two main paradigms alternative to nationalism. Criticizing the tendency in nationalism studies to conflate societies with nations (Wimmer and Glick Schiller 2002), transnationalism has shown how migrant lives exist across rather than within national territories (Basch, Glick Schiller, and 
Blanc-Szanton 1994). Accordingly, the nation has been dismissed as a bounded container which reduces complexity and plurality (Levitt 2012, Amelina and Faist 2012), whereas the transnational field has been heralded as a site of 'solidarity in diversity' which challenges the opposition between natives and immigrants produced by the very existence of national boundaries (Glick Schiller 2009, Dahinden 2016).

Cosmopolitanism has also operated a similar move beyond the nation-state. Although this term can be associated with a plurality of positions, from the moral call for the universal values of justice and right (Nussbaum 1994), to the political call for global governance (Archibugi 2004) and, again, to the cultural call for a global condition of hybridity, contamination and creolization (Vertovec and Cohen 2002, Cohen 2007, Pollock et al. 2000, Bhabha 1993), the common denominator is one of disputing the stability of territorialized identities (nation included), questioning the unity of the 'we' and the otherness of the 'other' (Antonsich and Matejskova 2015b).

Among geographers, transnationalism and cosmopolitanism have been equally instrumental in rethinking how living in diversity can be operationalized away from the nation to more local scales. ${ }^{2}$ To this end, since the early 2000s geographers have started focusing on the micro-publics of everyday encounters to generate a politics of transnational connectivity (Amin 2002) or cosmopolitan conviviality (to borrow Gilroy's (Gilroy 2004) term), beyond national cultures of belonging and identity (see (Wilson 2016) for a review). Within these accounts, the city - conceptualized as the main site of these everyday encounters - has been narrated in opposition to the nation: celebrated as dynamic, inclusive, heterogeneous, and empowering the former, dismissed as static, exclusive, homogeneous and constraining the latter (Rossetto 2015). 
The present article aims to look further into this divide, making the case for reconciling the local and the national within the context of increasingly diverse societies. In fact, while in time scholars have shown, both empirically (Baban 2006, Moran 2011, Brett and Moran 2011, Conway, Potter, and Bernard 2008) and normatively (Beck and Levy 2013, Hedetoft 2011, Delanty 2006, Calhoun 2008), that cosmopolitanism and transnationalism actually reframe rather than replace nationalism, this point does not seem to have fully informed the work of those geographers who continue to explore forms of living in diversity at the local scale and at the city level in particular. Within the majority of these works, the nation continues in fact to be either dismissed for its exclusive thrust or merely ignored.

Drawing on narratives of Italians with foreign background talking and writing about their individual experiences of living and growing up in Italy, this article explores the intersections between the local and the national. While there is substantial literature which has investigated the links between these two registers (Jones and Desforges 2003, Jones and Fowler 2007, Jones 2008, Appleton 2002, Confino and Skaria 2002), pointing out how the intersections between the local and the national scales, among others, organizes and makes make social life meaningful, little has been written on how these links operate in the presence of a diverse population. By incorporating this dimension, I show how 'the tale of two scales' (Rossetto 2015), which opposes the local and the national and which often characterizes geographical works on diversity, is too simplistic a reading. In fact, while participants in the present study often lamented their exclusion from the national imaginary, they also jointly activated local and national repertoires and, more importantly, they strategically mobilized the local (particularly through the use of the vernacular) as a way to claim their place in the nation. 
The article is divided into four sections. In what follows, I shall offer a broader discussion of the local/national divide as mainly occurring within geographical literature. The methodological section discusses the choice of Italy as a case study, offers contextual information, and illustrates how data was collected and analyzed. Empirical evidence is organized around two themes: the blurring of the local/national divide and the strategic use of the local for claiming a place in the nation. In the conclusion, I argue that by adding the national register to their studies scholars can offer more accurate accounts of how living in diversity is narrated and practiced within our contemporary societies.

\section{The local vs the national}

How to reconcile nation and diversity has long been a central theme in the research agenda of various disciplines. In normative terms, political theorists have tried to rework the meaning of nation, substituting its ethnic thrust with civic (Habermas 2001), liberal (Miller 2000, Kymlicka 2001), multicultural (Modood 2007, Parekh 2000) or intercultural (Bouchard 2011) principles (see Antonsich, 2014 for a review of these various positions). Geographers - and with them other social scientists - have been, however, skeptical or merely oblivious of these normative reflections. For many of them, the nation is irredeemably associated with a space of exclusion and the only possible answer to the living in diversity is to look beyond the nation. Accordingly, cosmopolitan and transnational registers have attracted considerable attention. Yet, contrary to some influential anthropologists, who in the early 1990s popularized the idea of the deterritorialization of identities (Appadurai 1996, Gupta and Ferguson 1992), geographers have argued that transnationalism and cosmopolitanism are emplaced phenomena (Ley 2004, Leitner 
and Ehrkamp 2006, Mitchell 1997). It is in transnationalized and cosmopolitanized locales often the city or neighborhoods within cities - that diversity can be and feel 'in place' (Cresswell, 1996).

Looking at this geographical literature, I would argue that there are two distinct, but related ways in which diversity has been said to feel 'at home' in local places. In the first case, the locale is imbued with ethnically and religious familiar repertoires and/or life experiences in phenomenological terms. For instance, in her study of Turkish immigrants living in Marxloh, a northern neighbourhood of the German city of Duisburg, Ehrkamp (Ehrkamp 2005) shows how transnational ties enable them to forge local attachments and a sense of belonging to the neighborhood, against a national context of discrimination and exclusion. The neighborhood acts as a sort of cocoon or, in the words of one of her participants, as "a protective wall" (Ehrkamp 2005: 360), where ethnically and religiously familiar places (mosques and teahouses) and people (Turkish immigrants and their descendants) offer a defense against the potential threat originating from the hosting nation. This attitude is certainly not specific of Turkish immigrants in Germany. It is reproduced for instance by children of Turkish immigrants also in France and in the Netherlands (Ersanilli and Saharso 2011) or by British Muslims in Britain (Phillips 2006), who equally experience a dissonance between their sense of inclusion in local places and exclusion at the national level (Isakjee 2016).

In a study by Wessendorf (Wessendorf 2010) on ‘second generation' Italians living in Switzerland, the locale is also juxtaposed to the nation, but rather than pointing to a familiarity in ethnic and religious terms, it is feelings of rootedness, insideness, and a sense of place, understood in phenomenological terms (Tuan 1977, Relph 1976), that come to the fore. As observed by one of her participants: "I can say I am Baselian, I am born here, and after all, I have 
done everything in this town. In Italy I go on holiday, what shall I say, I'm from C [southern Italian town] ... I don't even know these places, so I always said, hey, I am Italo-Baselian! ... At the beginning I did it because, I went to Italy and was told 'no you are Swiss', and I went up to Switzerland and was told I was Italian, then I thought 'hello, I'm from nowhere wherever I go!' and then I thought my connectedness is Basel, and the rest is not so important" (Wessendorf 2010: 374). While the nation is a register of exclusion, the locale, imbued with one's life experiences, is associated with feelings of belonging and identity. Similar phenomenological attachments to one's city and dis-identification with the nation also appear in other contexts, like for instance among youth of Chinese (Raffaetà, Baldassar, and Harris 2016) and Albanian (Vathi 2013) origin living respectively in Prato and Florence, Italy.

The second way in which the locale is 'home' to diversity is related to the idea of the city as a 'world of strangers' (Koefoed and Simonsen 2011), where marked visibility goes unnoticed, disappearing in the 'throwntogetherness' of urban life (Massey 2005: 181). Studying Danish citizens of Pakistani origin, Koefoed and Simonsen (Koefoed and Simonsen 2011: 343, 2012) for instance suggest that city and nation possess 'different qualities' when it comes to accommodate a diverse population; while the former is a space of habitability and identification, the latter is a source of discrimination. This point recurs in various other studies, which equally heralds the city in opposition to the nation for its 'ethos of mixing' (Wessendorf 2013, Kuppinger 2014), where ethnic and cultural complexity is not regarded, like at the national level, in terms of disorder and loss of coherence (Robins 2001), and where the very distinction between sameness and difference ceases to inform daily encounters (Georgiou 2013). In the city, in fact, social relations are regulated by mutual reserve and impersonal contacts (van Leeuwen 2010) - echoing 
Young's (Young 1986) civil indifference towards difference or Goffman's (Goffman 1972) civil inattention.

The city also becomes the spatial register where to rethink and ground the idea of citizenship, once again in opposition to the nation and its "implausible idea" of shared culture (Holston and Appadurai 1996: 192). This new urban citizenship rejects indeed essentialist notions of culture and identity (Uitermark, Rossi, and Van Houtum 2005), praises heterogeneity and plurality (Coward 2012) and, relying on the Lefebvrian 'right to the city' (Purcell 2002), calls for a post-national political space in which variously excluded groups of urban inhabitants could legitimately belong (Bauder 2016). Within geography, this move away from the nation to the city as a site to rethink the politics of identity and difference is maybe most clearly articulated in the work of Closs Stephens (Closs Stephens 2013). Building on the rich literature of everyday encounters (Amin 2002, Wilson 2011, Swanton 2010, Matejskova and Leitner 2011, Valentine 2008, Leitner 2012), but also departing from their search for the 'right places' where encounters can become meaningful, Closs Stephens argues for a politics that overcomes the space and time of nationalism. Accordingly, she portrays the city as a cosmopolitan space of encounters beyond the nationalist logic of unity, homogeneity, and linearity - a politics of coexistence organized not around identity, agreement, commonality and shared meanings, but formed through crossings, exchanges, and disagreements, as best captured in Nancy's (2003) concept of the mêlée (Antonsich et al. 2014).

All the above studies posit the nation and the local place (often the city or the urban neighborhood) in opposition. Very few studies have instead tried to explore the links between these two registers. Drawing on the insights of Jones and colleagues (Jones 2008, Jones and Desforges 2003, Jones and Fowler 2007), who have shown how local places intervene in 
reproducing the nation, these studies have tried to problematize the local/national divide in their analyses of immigration societies. Focusing on multicultural experiences in Birmingham, Wilson (Wilson 2015) for instance reflects on the role that this British city plays as a laboratory for more inclusive forms of national belonging. Similarly, Downing (Downing 2015, 2014) explores forms of governance in the French city of Marseille to support his argument about the role of cities as arenas for the redefinition of the national imaginary. Moving from a substantial to an experiential idea of nation, also Rossetto (Rossetto 2015) convincingly shows the simultaneous interplay of local and national registers in the accounts of immigrants living in Padua, Italy.

The present article aims to offer new empirical evidence to reassess the local/national divide, which seems to dominate the literature on diversity. The article argues that the boundaries of this divide are not only porous and blurred, but that in certain instances the local register (particularly through the use of the vernacular) is strategically mobilized to claim national belonging. In this sense, the article aims to advance extant scholarship on the intersections between the local and the national by studying how these two registers are simultaneously activated by individuals with foreign background. This might offer a more refined way to address how living in diversity is narrated and practiced within contemporary societies.

\section{Italy: the research context}

The chosen case study belongs to what scholars label as 'Mediterranean model of immigration’ (DeMaria Harney 2006, King and Black 1997). Together with Greece, Spain and Portugal, only recently has Italy transformed from a country of emigration to a country of 
immigration. Statistically the turning point was the year 1973, but the first considerable inflow took place in the mid-1980s (Zincone 1998). Being a relatively recent phenomenon, immigration to Italy has also been a relatively rapid one. On 1 January 2003, foreign nationals legally residing in the country amounted to $1,549,373$ individuals or $2.7 \%$ of the total population. About a decade later, on 1 January 2016 , this figure was up to $5,026,153$ persons or $8.3 \%$ of the total population (ISTAT 2017). Between 2003 and 2010, there was an average growth of $12.7 \%$ or 431,000 people a year (Ambrosini 2013a: 139). This rapid demographic change is associated with another feature of the 'Mediterranean model of immigration', namely a public ill-prepared for the settlement and incorporation of immigrants. Although international immigration is presently the first concern of citizens across Europe, in the case of Italy public attitudes towards immigrants are indeed far more negative (69\%) than the European average (56\%) (EuropeanCommission 2016: 30).

This negative view also seems to extend to the children of immigrants, despite the fact that they are born and raised in Italy (Andall 2002, Ambrosini 2013b). Their exact number is not known, but an estimate based on the latest census data (2011), adjusted by other demographic projections, puts this figure at between 800,000-900,000 individuals (AGI 2017). Most of them are not Italian citizens, for the Italian nationality law is still mainly based on jus sanguinis (blood line). Over the last sixteen years, various reform projects aiming at a moderate form of jus soli (citizenship based on territory of birth) have been proposed to the Parliament. On 13 October 2015, one of these proposals was approved by the lower house (Camera) of the Parliament and since then is awaiting final approval by the upper house (Senato). Despite the lobbying of various associations, including those formed by children of immigrants (e.g. Rete G2), a clear 
political majority which could finally pass the new nationality law has, however, proved difficult to form.

Although a clear discourse about 'we' (Italians) vs. 'them' (immigrants) populates the public sphere, being also instrumentalized by various political parties - the Northern League in particular (Caiani and Conti 2014) - the very notion of 'Italian' is historically a rather contested one. Having achieved territorial unification relatively late (1861), compared to other Western European nations, Italy has also been marred by a complex internal fragmentation. The most prominent one goes under the name of the 'Southern question' (Schneider 1998). Although originally this term indicated the economic backwardness of Italy's southern regions, in time it has also acquired a cultural dimension. The South has indeed been treated as an 'internal Other' against which to construct the image of a modern Italy (Johnson and Coleman 2012, Agnew 2000).

An additional socio-spatial fragmentation is also associated with a deeply-rooted sense of regionalism or localism so that, for someone, Italy only exists as a nation of compaesani or fellow local dwellers (Agnew 2002). The relatively recent political unification, the weakness of the state, and a diffuse urban polycentrism have indeed favored the preservation of local identities and traditions (Graziano 2010). Among these, the use of the vernacular is the most apparent feature. Although the standardization of the Italian language dates back to the mid-1 $17^{\text {th }}$ century (Stergios 2006), at the time of Italy's unification only $2.5 \%$ of the population could speak standard Italian (De Mauro 2017). Even when higher literacy levels were achieved in the second half of the $20^{\text {th }}$ century and the national television brought standard Italian in all the households, the use of dialects did not disappear. In 2006, dialect was used both in the family and among friends by, respectively, $75 \%$ and $70 \%$ of the population (De Renzo 2008: 57). 
According to De Mauro (De Mauro 2003), the coexistence and the mixing of Italian language and dialects should therefore be seen as a specific national trait.

Data for the present study comes from a larger project aimed at investigating the impact of the demographic change brought about by international migration on the idea of nation (www.newitalians.eu). Voices of children of immigrants constitute one of the three dimensions investigated (the other two being politico-institutional documentation and views of ordinary people without foreign background). These voices were collected by focusing on multiple sites. First, we identified the key associations of children of immigrants, in terms of national reach and presence on the web and social media. Since the early 2000s, children of immigrants have indeed created various associations, both local and national, with the main aim of sharing common individual experiences (Andall 2010). The key associations selected were Rete G2 (http://www.secondegenerazioni.it/), YallaItalia (http://www.yallaitalia.it/), Associna (http://www.associna.com/it/), and Giovani Musulmani d'Italia (GMI https://www.facebook.com/GiovaniMusulmanidItaliaGMI/). Although all of them are platforms where members can share their personal views and experiences, they also have specific remits: lobbying for a reform of the nationality law (Rete G2), bridging Italian and Chinese cultures (Associna), and creating a space for Islam in Italy (GMI). For all of them, we examined the content (forums, blogs, and videos) posted on the webpages since their creation. Our main interest was on notions of 'Italy' and 'Italian' as these emerged in relation to the personal experiences and views of their members. During the period July 2015 - July 2016, we also administered 30 semi-structured individual interviews (10 men, 20 women - aged 18-40, median age 29) with some of the most active members of the above associations. This was done in order 
to better understand the origin, rationale, and internal dynamics of the associations, as well as to further explore some of the themes which emerged from the analysis of the web-based data.

In addition, we also conducted an extensive search of the literary, musical and film production of children of immigrants, with the help of secondary sources which highlighted key contributions. We selected those authors who have explicitly addressed themes relevant to the present research and we administered, during the same period, a total of 13 semi-structured individual interviews ( 5 women and 8 men, aged 24-48, median age 34 ): 5 with writers, 3 with film directors, and 5 with rappers (hip-hop is the main musical genre adopted by Italian children of immigrants to voice their political claims - (Clò 2012)). Even in this case, our focus was on notions of 'Italy' and 'Italian' as emerging in the participants' works and conversations.

All interviewees were born in Italy or arrived at a very early age; they also had various ethnic, racial and religious backgrounds, thus reflecting the variegated composition of the population issued from immigration residing in Italy (ISTAT, 2017).

Data was collected with the help of Italian research assistants, whose previous experience of working with children of immigrants facilitated the recruitment and interviewing process. Content analysis was performed on the data collected which were coded via an 'analytic induction' approach (Crang 1997: 188) which, echoing grounded theory, relies on the iterative process of going back and forth between original data and theoretical concepts in order to reach successively more abstract categorizations. Translations of blog and interview excerpts used in this article are from the Author, who is a native Italian speaker. Interview data are presented anonymously, unless participants explicitly waved their right to anonymity for wishing to comment on their artistic production. 


\section{Between the local and the national}

The nation as a site of exclusion is a view clearly present within the analyzed data. Participants talked about their frustration and at times anger for the fact that the majority society did not look at them as Italians, despite the fact that they felt and identified as such. Speaking Italian fluently, sharing the same spaces, listening to the same music, watching the same TV programs, or enjoying the same food was not enough if their face was not perceived as an 'Italian face' (Antonsich, 2018). Some participants also observed how the rejection of their Italian identity was more common among the older generation, whereas their peers were much more at ease with phenotypical difference, thus pointing to the homogenizing role of the generational factor observed in other studies (Colombo, Leonini, and Rebughini 2009). Besides generation, also emotional proximity in terms of friendship allowed for phenotypical difference to go unnoticed, thus confirming in this case what Allport's (Allport 1954) contact theory has long suggested.

All in all, then, there is clear evidence that many participants confirmed the mainstream view of nation as a register ridden with discrimination, racism and indeed exclusion. The transnational register (often related to the connections to the country of origin of their parents) was also present in the accounts of the participants. Yet, contrary to the literature which posits it as alternative forms of identification in the presence of a nation which excludes (Andall 2002, Raffaetà, Baldassar, and Harris 2016, Vathi 2013, Benton and Gomez 2014), it was narrated as an additional resource along with rather than in opposition to the nation - a point equally evidenced in other studies (Colombo 2010). Related to this were also forms of self-identification 
in terms of hyphenated national identities, particularly among those individuals who seemed to have spent more time reflecting on their personal lives and among Black participants ('AfroItalian' was the term most frequently used). Despite the fact that the notion of hyphenated identities is only now appearing in the Italian public discourse, this form of self-identification is not surprising, because the overwhelming majority of participants did not question their being and feeling Italian, but they wished to be part of an Italian nation which could embrace their diverse background.

This point also relates to the ways in which the locale was narrated by the participants. Although, there is clear evidence that, particularly in Northern Italy, the locale is also a site of exclusivist policies, it was not necessarily mobilized in opposition to the nation. In fact, participants not only they blurred the boundaries of the local/national divide, but some of them also strategically mobilized one (locale) to claim a place in the other (nation). Away from a locale acting as a cocoon against the nation or as a space of strangers where diversity goes unnoticed, these participants emphasized their local attachment and identification as a way to strengthen their claim of national belonging. Here below I shall illustrate these two related positions in detail.

\subsection{Blurring the local/national divide}

My name is Wanda and I was born in Bologna in the mid-1980s. I am an Emiliana doc, apart from that strange surname [Moshfegh], difficult to pronounce, but easy to write it wrongly [...]. My parents are Iranian; at home we speak a mix of Farsi and Italian. [...] So how can I be Emiliana with that surname and my slight Middle-eastern features? Because 
I grew up here, because my alphabet is composed of 21 letters, because I always say

Sócc'mel [vulgar expression in Emilian dialect], because at Christmas I always eat tortellini, because in my bedroom I had to repeat the poems of Leopardi, and because Cristina D'Avena framed my childhood. ${ }^{3}$

In the passage above, Wanda identifies herself with Emilia, a portion of the Italian administrative region whose capital is Bologna. In order to explain why she feels Emiliana doc, i.e. an authentic person from Emilia, she resorts to some mundane national markers: the Italian alphabet, the learning of classic poems of the Italian tradition, the songs of Cristina D'Avena which populated many children cartoons in the 1980s. Scholars have widely investigated the importance of everyday practices in processes of national reproduction 'from below' (Jones and Merriman 2009, Fox and Miller-Idriss 2008, Edensor 2002, Skey 2011). Interestingly, though, these national markers intersect here more local ones (dialect expressions, eating habits), making impossible to draw a clear line between these two registers, as both equally intervene in the ways Wanda talk of herself.

In other accounts, the use of the vernacular returned frequently and tracking its use allows for an additional exploration of the intersections between the local and the national. Let's take, for instance, the following excerpt, which presents the exchange between a group of Rete G2 members in both Italian and dialect: ${ }^{4}$

Fang Ailing: How many of you here are from Bergamo?

El persiano: I don't want to disappoint you... but I think we are four 
FangAiling: haha ooonly haha and me that I was already thinking to get toch ensema a maja na pizza [all together to eat a pizza] haha

El persiano: eheheh cool... e tocc en sema a maja' pulenta e osei? sara' mia mej? [and all together to eat polenta and birds? Wouldn't it be better?] ahahah cool!!!

PurpleWoman: eh?!.. sorry I think I am on the wrong website ahahahahhaha FangAiling: $o k$ isè alura ${ }^{\wedge}$ [birds then]. But where about Bergamo you are from?

El persiano: No sister, you are not on the wrong website, in longobardia 035 [province of Bergamo] is like this! ... you know, it's nice to talk this way to the face of the integralists of Padania! ... bon, so cuntet [good, I am happy]... I live in the south-west of the province (Osio) and you?

FangAiling: you know the hyper market of Seriate... a bit further... basically in the fields just after hehe

Pipit: aho...'sti [hey...these] foreigners... but why nun s'emparano litaiano [they don't learn Italian]?! Sete initaia [you are in Italy] so speak itaiano [Italian]!! ${ }^{5}$

The above exchange shows an ironic use of the vernacular. Bergamo is known for its peculiar dialect, which is often mocked by other Italians. At the same time, in Northern Italy, the dialect might also be a politically-loaded medium, as it reminds of the sympathizers of the Northern League, the political party which once campaigned for the independence of the North (Agnew 1995) and which has now become a far-right populist and nationalist party (Vampa and McDonnell 2016). Apparently mocking both - Bergamo's dialect speakers and Northern League's sympathizers (referred above as "integralists of Padania") - the participants playfully switch between Italian and vernacular, reproducing what is indeed a common practice among 
Italians (De Renzo 2008). The final comment is particularly telling, as the expression "why these foreigners don't learn Italian?" is a lamentation frequently heard in public discourses regarding immigrants and it is often, paradoxically, expressed in vernacular. This is fully captured by the participant who, artfully using Romanesco (the dialect spoken in Rome), ironically exposes this paradox, as the demand of national assimilation is a demand framed in vernacular terms. It once again reveals an instance where the local and the national conflate, for the only possible way to be Italian is through the mediation of the local register. This is an important point, which recalls the observation by Valentine et al. $(2008,385)$ on the mutually constitutive relation among language, identity, and place: "you are what you speak, and what you speak is where you are". In the case of Italy, where each region features a plurality of vernaculars (Alfonzetti 2013), national incorporation and local incorporation conflate. The 'tale of two scales' (Rossetto 2015) here breaks down, as it is impossible to juxtapose one against the other. Children of immigrants are Italians insofar as they are locally embedded, exactly like any other Italian. Let's consider for instance the following exchange:

C: it's very easy to judge a person from their appearance, right? It's something we all do, unconsciously, and if one sees an Asian girl with Asian traits and almond eyes etc., ok, she must be Chinese, she does not speak Italian, she is impenetrable and keep going with other prejudices

Interviewer: well, but you have a Turin accent!

C: (laughing) you bet! I have the most Piedmontese accent of all Piedmont, I reckon! Interviewer: (laughing) yes, yes, as a Milanese I can see that C: (laughing) yes! 
In this excerpt, the research assistant who interviews $\mathrm{C}$, a young woman born and raised in Turin to Chinese parents, shows a sense of surprise in hearing a marked Turin's accent, confirming that linguistic sameness in a foreign body is also something unexpected among educated Italians sympathetic to diversity. In the above exchange, an empathic 'we-feeling' is generated by exactly sharing a similar vernacular embeddedness. Contrary to Puwar (Puwar 2004: 111-112), who suggests that speaking the national language properly, not the local vulgate, allows for a foreign body to be perceived less foreign, in the case of Italy the opposite seems true.

Local and national were not always activated alone. As mentioned, in some cases the transnational scale also entered the accounts of the participants, often in the form of references to the countries of origin of their parents or in the form of linguistic expressions. This can be illustrated with the case of Valentino AG, a hip-hop singer born in Rome to Nigerian parents, who wrote and performed the sound-track of the short film 18 Ius Soli (2011) by Fred Kuwornu. The movie is a political call for reforming the nationality law and legally recognizing as Italians children of immigrants who are de facto Italians. The title of the song, Sono nato qui (I was born here), is equally a claim to citizenship for someone who was born and raised in Italy. Yet, again, this expression of national belonging mixes Italian, Romanesco and also English, the language which connects the Black diaspora to which Valentino AG also belongs. As he observed during our interview:

This song was born for a documentary [18 Ius Soli] and I wrote it for remarking that everyone has their origins... and my cadence, the natural and spontaneous one, is the 
Romanesco [...] I wanted to show where I come from. I am not Rocky Roberts [an American-born Italian R\&B singer who became famous in Italy in the 1960s] who sing in 'Ital-English' [Italian with a strong American accent], but I sing in 'Ital-Romanesco' [laughing]. That's it. I felt I wanted to introduce myself this way. ${ }^{6}$

Here, the local intersects the transnational, as already extensively studied by geographical literature on diversity (Ley 2004, Leitner and Ehrkamp 2006, Mitchell 1997). Yet, the national is also very much present, both in the form of a citizenship claim and as a performative linguistic expression. It is therefore not surprising that, in other instances, the intersection between the local and the national was more purposely deployed to claim a place in the nation. In the next section, I shall focus in detail on two examples which illustrate this point.

\subsection{The local claims the national}

Forte e Chiaro (Loud and Clear) is the video co-produced in 2005 by a Rome-based group of children of immigrants who later in the year, also thanks to this collaborative project, were to create Rete G2 - today, the most prominent association of children of immigrants nation-wide. ${ }^{7}$ Originally self-funded, the video attracted the interest of political institutions and the public more broadly: its post-production was made possible by funding from the Italian Ministry for Social Solidarity of the center-left Prodi government; it was screened in the lower house of the Parliament; and it circulated widely in schools and film festivals both in Italy and abroad. The video features various Rete G2 members who in turn voice their personal experiences and 
frustrations for lacking Italian citizenship. They appear in an open-air location in Rome; the backdrop is particularly significant, as it is a mural made by the artist Gian Maria Tosatti with excerpts from Camus's novel The Outsider. In the aims of Rosa Jijon and Maya Llaguno Ciani, respectively the film director and script writer, the participants were asked to freely perform their own citizenship claims. The intention was to create a video where the message of belonging to the nation was narrated through the language freely chosen by the participants. ${ }^{8}$ Accordingly, while some of them talked in standard Italian, others explicitly resorted to Romanesco, the vernacular of the city where they were from. In the opening of the video, a Rastafarian Black Italian, heavily gesticulating, says: "Tu ammé me vedi come seconda classe: Io, a' te t'accanno" [You see me as second class: I'll beat you up]. Later in the video, the same person, talking into a phone in hip-hop style, affirms: “Jo so' Romano, che te pare? un turista?" [I am from Rome, what do you think that I am? A tourist?]. In another passage, another participant with a heavy Romanesco accent observes: "Immigrant to me? Well, maybe yes, immigrant from San Basilio to Casal Lombroso [Rome's peripheral areas]". The message cannot be clearer: local rootedness, emphasized by the deliberate use of the vernacular, is what legitimizes them as Italians and therefore make them entitled to Italian citizenship. This performance clearly evokes what Koefoed and Simonsen (Koefoed and Simonsen 2012: 639), echoing Smith (1992), call 'jumping scales', the practice of children of immigrants to move from one identification scale to another. As shown by Colombo and Rebughini (2012), this is indeed a practice fairly common among children of immigrants, Italian included. Yet, rather than jumping from the locale to the transnational, like in the accounts Koefoed and Simonsen examined, participants in this video deliberately use the locale as a trampoline to jump onto the nation. Jijon, the film director, recalls that when the video was screened in Milan, the audiences were positively amused and 
commented "but these are really Romani! [people from Rome]". In this comment, skin color, eyes' shape and any other phenotypical marker pass unnoticed, for a sense of national familiarity is indeed generated by the possibility to clearly locate these children of immigrants in a wellknown vernacular.

Another instance where local rootedness, in the form of dialect, was strategically mobilized to claim a place in the nation is the short movie GeNEWration. Secondi a nessuno, by Amin Nour, in collaboration with Pietro Tamaro. ${ }^{9}$ Born in Mogadishu, Somalia, Nour came to Italy when he was three years old and settled with his mother in Rome. The movie is about Italy's 'second generation', as the wordplay of the title suggests - 'a new generation, second to none'. The setting is a bar not far from Rome's Termini train station (one of the principal meeting points of immigrants in Rome), where a group of male friends, both with and without immigrant background, hang around. According to Nour, the bar stands for the place where ordinary Italians usually gather, often to watch football. ${ }^{10}$ It is therefore a symbolic space to stage the nation. By portraying the above group of friends sharing this setting, chatting about girls and getting excited when the TV shows Rome playing AC Milan, Nour's aim is to underline how the 'second generation' is no different from any other Italian. Particularly significant is that the movie opens and ends with the chorus of a song by the Italian-Egyptian rapper Amir: "People confused me with an immigrant/With the face of a foreigner in my nation/ The future here is the second generation". Both this chorus and the whole movie's script aim to remark how the 'second generation' is no foreign to Italy. Yet, once again, this claim of national belonging is purposely voiced in vernacular. All the characters in the movie, despite their backgrounds, speak Romanesco. This situated practice not only connects people to the local place (Valentine, Sporton, and Nielsen 2008), but also to the larger place which is the nation, as confirmed by 
Nour: "many second generations are often attached to the dialect exactly because they mark their Italianness in the region where they live. Speaking dialect allow them to be somewhat accepted" ${ }^{11}$ It is particularly interesting that the only characters which do not speak vernacular in the movie are a young white couple, which sitting uncomfortably at one of the bar's tables comments: "What a smell! These people don't wash themselves, you know" - a short reminder that a racialized understanding of nation is always present and yet isolated in a context where a sense of togetherness in diversity is built around a shared vernacular.

Both Forte e Chiaro and GeNEWration are instances in which the local scale, in the form of the vernacular, is consciously and actively mobilized to claim a place in the nation. This challenges once again the 'tale of two scales' which seems to operate with a rather rigid scalar thinking; one which associates the local/urban and the nation with distinct and opposed ontological qualities: progressive, plural and inclusive the former and parochial, homogenizing, and exclusionary the latter. Evidence in this article breaks these ontological boundaries, pointing instead to the representational character of these scales (Jones, 1998), which can both assume different configurations of inclusion/exclusion. It also highlights the agency of 'diverse' people when it comes to the national scale. Far from reproducing the 'tale of two scales', these individuals trespass the boundaries which locate them in one place (local/urban) and not in the other (national), thus reaffirming the relational and co-constitutive nature of these two scales.

\section{Conclusion}


As societies in Europe and elsewhere are undergoing a "transition to diversity" spurred in great part by immigration (Alba and Foner 2014: S266), living in diversity remains the focus of continued attention. Critiquing the nation-state as a bounded container which reduces complexity and plurality (Wimmer and Glick Schiller 2002, Basch, Glick Schiller, and Blanc-Szanton 1994, Levitt 2012, Amelina and Faist 2012), various scholars have focused on alternative socio-spatial registers. The transnational in particular has emerged, since the 1990s, as the new site where to map the ways diversity is lived and narrated. Espousing this view, geographers have convincingly shown the links between transnationalism and local places (Leitner and Ehrkamp 2006, Ehrkamp 2005). On a related move, geographers and other social scientists have also stressed the importance of the city as a locus of cosmopolitan conviviality founded not on shared identity, but on a politics of connectivity produced by everyday encounters between urban strangers (Amin 2002, Koefoed and Simonsen 2011, Closs Stephens 2013). In both moves, though, the nation has often been left out of the picture, since the local place and the city in particular have been theorized in opposition to the nation itself.

The present article has analyzed empirical evidence which allows for a different understanding of the role that the nation plays in relation to diverse societies. By focusing on textual and visual accounts of children of immigrants born and raised in Italy, the article has explored the ways in which local and national registers intersect in the life stories of the participants. Although there is clear evidence of a nation activated by the majority society as an ethno-racial exclusive space, this did not trigger, among the participants, narratives of a locale juxtaposed to the nation, in transnational or cosmopolitan terms - what in the article has been referred to as the 'tale of two scales' (Rossetto, 2015). On the contrary, two major findings emerge from the accounts analyzed: the blurring of the local/national divide and the strategic use 
of the local register to claim national belonging. First, the local place did not emerge as a homely space where to feel secure within the 'hosting' nation, for the sense of local attachment, belonging and identification expressed by the participants was closely imbricated with national markers - and the other way round. To trace a divisive line between these two registers and to herald, on the one hand, the local place - the city or the neighborhood within the city - as a site where diversity can find its place and, on the other hand, the nation as a site where diversity is 'out of place' would fail to capture the ways in which participants appealed to the nation while narrating their sense of local belonging. Second, in some instances participants also purposely mobilized local markers (the vernacular in particular) to claim their place within the Italian nation, offering therefore further evidence to challenge the 'tale of two scales' (Rossetto 2015) so prominent in the literature addressing the question of living in diversity.

These findings should invite scholars investigating the transition to diversity of contemporary societies to pay closer attention to the nation rather than eschewing it or treating it as a mere site of exclusion and discrimination. To be clear, the nation can certainly be activated as an exclusive site, but not only so. Accordingly, the task ahead is to see how the nation intervenes in informing life in diverse societies along with, rather than in opposition to local, transnational and cosmopolitan registers. This not just because there is empirical evidence that points in this direction, as the present article has shown, but also because, theoretically, to exclusively portray the nation as a homogenous, unified, and mono-cultural register risks reproducing the myth of a stable, coherent, organic nation-state which historically has never been (Chernilo 2006). Paradoxically, this would also reify the very methodological nationalism that scholars have tried to overcome. And yet, while earlier accounts of transnational and cosmopolitan urbanism (Amin 2002) acknowledged the importance of the national register for 
understanding forms of living in diversity, later contributions - particularly those within geographies of urban encounters - seem not to have followed suit on this indication.

One way of doing this is to build on the geographical literature which has explored the links between the local and the national scales. Along with Agnew (Agnew 2002), Jones and colleagues (Jones and Desforges 2003, Jones and Fowler 2007) have for instance aptly demonstrated how the local place is an essential component in processes of national reproduction. This scholarship would offer a theoretical and empirical basis from which to study forms of living in diversity which do not privilege the local or urban place at the expense of the nation. When narrated by individuals with foreign background, this latter in fact is not only a "site of estrangement" (Koefoed and Simonsen 2012: 6), which has to be by-passed in favor of sub-, supra-, or trans-national registers; but it can also be a site of affiliation, attachment and identification. Reproducing the 'tale of two scales' would only reify the local and the national as possessing intrinsic ontological qualities, thus obliterating those insights which instead maintain not only the social constructedness of scales, but also their relational character (Herod and Wright, 2002; Howitt, 2003; Amin, 2002b).

Although in the case of Italy, the national register was often articulated through the use of the vernacular, future studies could explore which additional local markers might become salient in other geographical contexts. Rather than overlooking or wishing the nation away, to explore how this register continues to be activated along other scales would offer a more accurate understanding of how living in diversity is narrated and practiced within contemporary societies. In an epoch when populist nationalism seems to fill the meaning of nation exclusively with xenophobic and racialized tones, to explore how the nation continues to inform the lifeworlds and sociality of a multicultural populace seems a timely research endeavor. 


\section{Acknowledgments:}

The data collection would have not been possible without the help of Silvia Camilotti, Lorenzo Mari, Stefano Pasta, Valeria Pecorelli, and Sonia Pozzi. Thank you to John Harrison, Tania Rossetto, Michael Skey, Peny Sotiropoulou, and Leila Wilmers for their valuable comments. This work was supported by the European Commission under Grant PCIG13-GA-2013-618470. 


\section{References}

AGI (2017). Lo 'ius soli' darebbe la cittadinanza a un milione di minori stranieri: Agenzia Giornalistica Italiana. http://www.agi.it/factchecking/2017/02/23/news/ius_soli_legge_stranieri_migranti_cittadinanza-1524349/

Agnew, J. (1995). The rhetoric of regionalism: the Northern League in Italian politics: 1983-94. Transactions of the Institute of British Geographers, 20(2),156-172.

Agnew, J. (2000). Italy's island other: Sicily's history in the modern Italian body politic. Emergences 10(2), 301-311.

Agnew, J.A. (2002). Place and politics in modern Italy. Chicago: University of Chicago Press.

Alba, R. \& Foner, N. (2014). Comparing Immigrant Integration in North America and Western Europe: How Much Do the Grand Narratives Tell Us? International Migration Review 48(s1), S263-S291.

Alfonzetti, G. (2013). The conversational dimension in code-switching between Italian and dialect in Sicily. In P. Auer (Ed.), Code-switching in conversation: Language, interaction and identity, (pp.180-211). London: Routledge.

Allport, G.W. (1954). The nature of prejudice. Cambridge, MA: Perseus Books

Ambrosini, M. (2013a). Immigration in Italy: Between Economic Acceptance and Political Rejection. Journal of International Migration and Integration, 14(1), 175-194.

Ambrosini, M. (2013b). 'We are against a multi-ethnic society': policies of exclusion at the urban level in Italy. Ethnic and Racial Studies, 36(1),136-155. 
Amelina, A., \& Faist, T. (2012). De-naturalizing the national in research methodologies: key concepts of transnational studies in migration. Ethnic and Racial Studies, 35(10), 17071724.

Amin, A. (2002a). Ethnicity and the multicultural city: living with diversity. Environment and Planning A 34, 959-980.

Amin, A. (2002b). Spatialities of Globalisation. Environment and Planning A 34: 385-399.

Andall, J. (2002). Second-generation attitude? African-Italians in Milan. Journal of Ethic and Migration Studies 28(3), 389-407.

Andall, J. (2010). The G2 network and other second-generation voices: Claiming rights and transforming identities. In J. Andall \& D. Duncan (Eds.), National Belongings: Hybridity in Italian Colonial and Postcolonial Cultures (pp. 171-194). Bern: Peter Lang.

Antonsich, M. (2018) The face of the nation. Troubling the sameness-strangeness divide in the age of migration. Transactions of the Institute of British Geographers, forthcoming.

Antonsich, M.(2014) Living together in diversity. A journey from scholarly views to people's voices and back. Bollettino della Società Geografica Italiana, Serie XIII, vol. VII, pp. 317-337.

Antonsich, M., Fortier, A.-M., Darling, J., Wood, N. \& Closs Stephens, A. (2014). Reading Angharad Closs Stephens's The Persistence of Nationalism. From imagined communities to urban encounters. Political Geography 40, 56-63.

Antonsich, M., \& Matejskova, T. (2015a). Conclusion: Nation and diversity - A false conundrum. In T. Matejskova \& Antonsich, M. (Eds.), Governing Through Diversity (pp. 201-209). Basingstoke: Palgrave. 
Antonsich, M., \& Matejskova, T. (2015b). Immigration societies and the question of 'the National'. Ethnicities 15(4), 495-508.

Appadurai, A. (1996). Modernity at large. Minneapolis: University of Minnesota Press.

Applegate, C. (1990). A nation of provincials: The German idea of Heimat. Berkeley: University of California Press.

Appleton, L. (2002). Distillations of something larger: the local scale and American national identity. Cultural Geographies, 9(4), 421-447.

Archibugi, D. (2004). Cosmopolitan Democracy and its Critics: A Review. European Journal of International Relations, 10(3), 437-473.

Baban, F. (2006). From gastarbeiter to “Ausländische Mitbürger”: postnational citizenship and in-between identities in Berlin. Citizenship studies, 10(2), 185-201.

Bail, C.A. (2008). The configuration of symbolic boundaries against immigrants in Europe. American sociological review, 73(1), 37-59.

Basch, L., Glick Schiller, N., \& Blanc-Szanton, C. (Eds). 1994. Nations Unbound. New York: Gordon\&Breach.

Bauder, H. (2016). Possibilities of urban belonging. Antipode, 48(2), 252-271.

Beauchamp, Z. (2017). White riot.Vox. http://www.vox.com/2016/9/19/12933072/far-rightwhite-riot-trump-brexit.

Beck, U., \& Levy, D. (2013). Cosmopolitanized nations: re-imagining collectivity in world risk society. Theory, Culture \& Society, 30(2), 3-31.

Benton, G., \&Terence Gomez, E. (2014). Belonging to the nation: generational change, identity and the Chinese diaspora. Ethnic and Racial Studies, 37(7), 1157-1171.

Bhabha, H.K. (1993). The Location of Culture. New York: Routledge. 
Bouchard, G. (2011). What is interculturalism? McGill Law Journal, 56(2), 435-468.

Brett, J., \& Moran, A. (2011). Cosmopolitan nationalism: Ordinary people making sense of diversity. Nations and Nationalism, 17(1), 188-206.

Brown, W. (2009). Regulating aversion. Princeton: Princeton University Press.

Brubaker, R. (2017). Between nationalism and civilizationism: the European populist moment in comparative perspective. Ethnic and Racial Studies:1-36 (online first).

Caiani, M., \& Conti, N. (2014). In the name of the people: The Euroscepticism of the Italian radical right. Perspectives on European Politics and Society, 15(2), 183-197.

Calhoun, C. (2008). Cosmopolitanism and nationalism. Nations and Nationalism, 14(3):427-448.

Chernilo, D. (2006). Social theory's methodological nationalism. Myth and reality. European Journal of Social Theory, 9(1), 5-22.

Clò, C. (2012). Hip Hop Italian Style. The Postcolonial Imagination of Second-Generation Authors in Italy. In C. Lombardi-Diop \& C. Romeo (Eds) Postcolonial Italy (pp. 275291). New York: Palgrave.

Closs Stephens, A. (2013). The Persistence of Nationalism. London: Routledge.

Cohen, R. (2007). Creolization and cultural globalization: the soft sounds of fugitive power. Globalizations, 4(3), 369-384.

Colombo, E. (2010). Figli di migranti in Italia. Torino: UTET.

Colombo, E., Leonini, L., \& P. Rebughini. 2009. Different but not stranger: Everyday collective identifications among adolescent children of immigrants in Italy. Journal of Ethnic and Migration Studies, 35(1), 37-59.

Colombo, E. \& P. Rebughini, eds. (2012). Children of immigrants in a globalized world: a generational experience. Basingstoke: Palgrave. 
Confino, A., \& Skaria, A. (2002). The local life of nationhood. National Identities, 4(1), 7-24.

Conway, D., Potter, R.B., \& Bernard, G. (2008). Dual citizenship or dual identity? Does ‘transnationalism' supplant 'nationalism' among returning Trinidadians? Global Networks, 8(4), 373-397.

Coward, M. (2012). Between us in the city: materiality, subjectivity, and community in the era of global urbanization. Environment and Planning D, 30(3), 468-481.

Crang, M. (1997). Analyzing qualitative materials. In R. Flowerdew \& D. Martin, Methods in human geography (pp. 183-196). Edinburgh: Longman.

Cresswell, T. (1996). In place-out of place. Minneapolis: University of Minnesota Press.

Dahinden, J. (2016). A plea for the 'de-migranticization'of research on migration and integration. Ethnic and Racial Studies, 39(13), 2207-2225.

De Mauro, T. (2003). Il plurilinguismo come tratto costitutivo dell'identità italiana ed europea. Synergies Italiae, 1, 19-25.

De Mauro, T. (2017). Storia linguistica dell'Italia unita. Roma-Bari: Laterza.

De Renzo, F. (2008). Per un'analisi della situazione sociolinguistica dell'Italia contemporanea. Italiano, dialetti e altre lingue. Italica, 85(1), 44-62.

Delanty, G. (2006). Nationalism and cosmopolitanism. In G. Delanty and K. Kumar (Eds), The SAGE Handbook of Nations and Nationalism (pp. 357-368). Thousand Oaks, CA: SAGE.

DeMaria Harney, N. (2006). The alternative economies of emigration and immigration, the real and the constitution of Italian nation spaces. Mobilities, 1(3), 373-390.

Downing, J. (2014). Contesting and re-negotiating the national in French cities: examining policies of governance, Europeanisation and co-option in Marseille and Lyon. Fennia, 193(2), 185-197. 
Downing, J. (2015). Understanding the (Re) Definition of Nationhood in French Cities: A Case of Multiple States and Multiple Republics. Studies in Ethnicity and Nationalism, 15(2), $336-351$.

Edensor, T. (2002). National identity, popular culture and everyday life. Berg Oxford.

Ehrkamp, P. (2005). Placing identities: Transnational practices and local attachments of Turkish immigrants in Germany. Journal of Ethnic and Migration Studies, 31(2), 345-364.

Ersanilli, E., \& Saharso, S. (2011). The settlement country and ethnic identification of children of Turkish immigrants in Germany, France, and the Netherlands: What role do national integration policies play? International Migration Review, 45(4), 907-937.

European Commission (2016). Standard Eurobarometer 86.2. Brussels: European Commission.

Fox, J.E., \& Miller-Idriss, C. (2008). Everyday nationhood. Ethnicities, 8(4), 536-563.

Gellner, E. (1983). Nations and Nationalism. Oxford: Blackwell.

Georgiou, M. (2013). Media and the city. Cambridge: Polity.

Gilroy, P. (2004). After empire. London: Routledge.

Glick Schiller, N. (2009). A Global perspective on transnational Migration. Oxford: COMPAS Working Paper No. 67.

Goffman, E. (1972). Relations in public. New York: Harper\&Row.

Goodhart, D. 2017. The Road to Somewhere. London: Hurst\&Co.

Graziano, M. (2010). The failure of Italian nationhood. London: Palgrave.

Gupta, A., \& Ferguson, J. (1992). Beyond "Culture": Space, Identity, and the Politics of Difference. Cultural Anthropology, 7(1), 6-23.

Habermas, J. (2001). The Postnational Constellation. Cambridge, Mass: MIT. 
Hedetoft, U. (2011). Is nationalism and anachronism? Notes on the mutations of national idealism in a global age. In M. Barrett, C. Flood, \& J. Eade (Eds), Nationalism, ethnicity, citizenship (pp. 13-34). Newcastle upon Tyne: Cambridge Scholars Publishing.

Herod, A. \& M.W. Wright, Eds. (2002). Placing Scale. Oxford: Blackwell.

Hochschild, J.L., \& Lang, C. (2011). Including Oneself and Including Others: Who Belongs in My Country? The Annals of the American Academy of Political and Social Science, 634(1), 78-97.

Holston, J., \& Appadurai, A. (1996). Cities and citizenship. Public Culture, 8(2), 187-204.

Howitt, R. (2003). Scale. In Agnew, J., K. Mitchell, \& G. Toal (Eds) A Companion to Political Geography (pp. 138-157). Oxford: Blackwell.

Inglehart, R., \& Norris, P. (2016). Trump, Brexit, and the Rise of Populism: Economic HaveNots and Cultural Backlash. Harvard Kennedy School, Working Paper No. RWP16-026

Isakjee, A. (2016). Dissonant belongings: The evolving spatial identities of young Muslim men in the UK. Environment and Planning A, 48(7), 1337-1353.

ISTAT (2017). Demografia in cifre. Rome: ISTAT.

Johnson, C., \& Coleman, A. (2012). The internal other: Exploring the dialectical relationship between regional exclusion and the construction of national identity. Annals of the Association of American geographers, 102(4), 863-880.

Jones, R. (2008). Relocating nationalism: On the geographies of reproducing nations. Transactions of the Institute of British Geographers, 33(3), 319-334.

Jones, R., \& Desforges, L. (2003). Localities and the reproduction of Welsh nationalism. Political Geography, 22(3), 271-292. 
Jones, R., \& Fowler, C. (2007). Placing and scaling the nation. Environment and Planning D, 25(2), 332-354.

Jones, R., \& Merriman, P. (2009). Hot, banal and everyday nationalism: Bilingual road signs in Wales. Political Geography, 28(3), 164-173.

Kaufmann, E. (2017). 'Racial Self-Interest' is not Racism. London: Policy Exchange.

King, R., \& Black, R. (Eds). 1997. Southern Europe and the new immigrations. Brighton: Sussex Academic Press.

Koefoed, L., \& Simonsen, K. (2011). 'The stranger', the city and the nation: On the possibilities of identification and belonging. European Urban and Regional Studies, 18(4), 343-357.

Koefoed, L., \& Simonsen, K. (2012). (Re)scaling identities: Embodied others and alternative spaces of identification. Ethnicities, 12(5), 623-642.

Kuppinger, P. (2014). Cinderella Wears a Hijab: Neighborhoods, Islam, and the Everyday Production of Multiethnic Urban Cultures in Germany. Space and Culture, 17(1), 29-42.

Kymlicka, W. (2001). Politics in the Vernacular. New York: Oxford University Press.

Leitner, H. (2012). Spaces of encounters: Immigration, race, class, and the politics of belonging in small-town America. Annals of the Association of American Geographers, 102(4), 828-846.

Leitner, H., \& Ehrkamp, P. (2006). Transnationalism and migrants' imaginings of citizenship. Environment and Planning A 38, 1615-1632.

Levitt, P. (2012). What's wrong with migration scholarship? A critique and a way forward. Identities, 19(4), 493-500.

Ley, D. (2004). Transnational spaces and everyday lives. Transactions of the Institute of British Geographers, 29(2), 151-164. 
Massey, D. (2005). For space. London: Sage.

Matejskova, T., \& Leitner, H. (2011). Urban encounters with difference: The contact hypothesis and immigrant integration projects in eastern Berlin. Social \& Cultural Geography, 12(7), 717-741.

McLaren, L. (2003). Anti-immigration prejudice in Europe: Contact, threat perception, and preferences for the exlcusion of migrants. Social Forces, 81(3), 909-936.

Miller, D. (2000). Citizenship and National Identity. Cambridge: Polity Press.

Mitchell, K. (1997). Transnational discourse: bringing geography back in. Antipode, 29(2), 101114.

Modood, T. (2007). Multiculturalism. Cambridge: Polity Press.

Moran, A. (2011). Multiculturalism as nation-building in Australia: Inclusive national identity and the embrace of diversity. Ethnic and Racial Studies, 34(12), 2153-2172.

Nussbaum, M. (1994). Patriotism and cosmopolitanism. Boston Review, 19(5), 3-16.

Parekh, B. (2000). Rethinking multiculturalism. London: Macmillan Press.

Phillips, D. (2006). Parallel lives? Challenging discourses of British Muslim self-segregation. Environment and Planning D, 24(1), 25-40.

Pollock, S.I., Bhabha, H.K., Breckenridge, C.A., \& Chakrabarty, D. (2000). Cosmopolitanisms. Public Culture, 12(3), 577-589.

Purcell, M. (2002). Excavating Lefebvre: The right to the city and its urban politics of the inhabitant. GeoJournal, 58(2-3), 99-108.

Puwar, N. (2004). Space invaders. Oxford: Berg. 
Raffaetà, R., Baldassar, L., \& Harris, A. (2016). Chinese immigrant youth identities and belonging in Prato, Italy: Exploring the intersections between migration and youth studies. Identities, 23(4), 422-437.

Relph, E. (1976). Place and Placelessness. London: Pion.

Robins, K. (2001). Becoming anybody: thinking against the nation and through the city. City, 5(1), 77-90.

Rossetto, T. (2015). Performing the nation between us: urban photographic sets with young migrants. Fennia, 193(2), 165-184.

Schneider, J., (Ed) (1998). Italy's 'Southern Question'. Oxford: Berg.

Shapiro, M.J. (1997). Narrating the nation, unwelcoming the stranger: Anti-immigration policy in contemporary 'America'. Alternatives, 22(1), 1-34.

Sides, J., \& Citrin, J. (2007). European opinion about immigration: the role of identities, interests, and information. British Journal of Political Science 37, 477-504.

Simon, R.J., \& Sikich, K.W. (2007). Public attitudes toward immigrants and immigration policies across seven nations. International Migration Review, 41(4), 956-962.

Skey, M. (2011). National belonging and everyday life. Basingstoke: Palgrave.

Smith, N. (1992). Geography, difference and the politics of scale. In I.J. Dorety, E. Graham, \& M. Mallek (Eds), Postmodernism and the social science (pp. 57-79). London: Macmillan.

Stergios, J. (2006). Language and nationalism in Italy. Nations and Nationalism, 12(1), 15-33.

Swanton, D. (2010). Flesh, metal, road: tracing the machinic geographies of race. Environment and Planning D, 28(3), 447-466.

Tuan, Y.-f. (1977). Space and Place. Minneapolis: University of Minnesota Press. 
Uitermark, J., Rossi, U., \& Van Houtum, H. (2005). Reinventing multiculturalism: urban citizenship and the negotiation of ethnic diversity in Amsterdam. International Journal of Urban and Regional Research, 29(3), 622-640.

Valentine, G. (2008). Living with difference: reflections on geographies of encounter. Progress in Human Geography, 32(3), 323-337.

Valentine, G., Sporton, D., \& Bang Nielsen, K. (2008). Language use on the move: sites of encounter, identities and belonging. Transactions of the Institute of British Geographers, 33(3), 376-387.

Vampa, D., \& McDonnell, D. (2016). The Italian Lega Nord. In R. Heinisch \& O. Mazzoleni Understanding Populist Party Organisation (pp. 105-129). Basingstoke: Palgrave.

van Leeuwen, B. (2010). Dealing with urban diversity: Promises and challenges of city life for intercultural citizenship. Political Theory, 38(5), 631-657.

Vathi, Z. (2013). Transnational orientation, cosmopolitanism and integration among Albanianorigin teenagers in Tuscany. Journal of Ethnic and Migration Studies, 39(6), 903-919.

Vertovec, S., \& Cohen, R. (Eds). 2002. Conceiving cosmopolitanism. Oxford: Oxford University Press.

Weber, E. (1976). Peasants into Frenchmen. Stanford: Stanford University Press.

Wessendorf, S. (2010). Local attachments and transnational everyday lives: second-generation Italians in Switzerland. Global Networks, 10(3), 365-382.

Wessendorf, S. (2013). Commonplace diversity and the 'ethos of mixing': perceptions of difference in a London neighbourhood. Identities, 20(4), 407-422.

Wilson, H.F. (2011). Passing propinquities in the multicultural city: the everyday encounters of bus passengering. Environment and Planning A, 43(3), 634-649. 
Wilson, H.F. (2015). An urban laboratory for the multicultural nation? Ethnicities, 15(4), 586604.

Wilson, H.F. (2016). On geography and encounter Bodies, borders, and difference. Progress in Human Geography. doi: 10.1177/0309132516645958

Wimmer, A., \& Glick Schiller, N. (2002). Methodological nationalism and beyond: nation-state building, migration and the social sciences. Global Networks, 2(4), 301-334.

Young, I.M. (1986). The ideal of community and the politics of difference. Social Theory and Practice, 12(1), 1-26.

Zincone, G. (1998). Illegality, enlightenment and ambiguity: A hot Italian recipe. South European Society and Politics, 3(3), 45-82.

\footnotetext{
${ }^{1}$ I use the term 'diversity' here in a rather descriptive manner, as a way to account for the above mentioned variation, without investigating the processual character and the power dynamics at work in the formation of these categories and without loading 'diversity' with any positive or negative value, as for instance in some debate between 'diversity' and 'difference' (Kobayashi, 1997; Eriksen, 2006; Modood, 2011).

${ }^{2}$ Contra to the more common 'living with diversity' (see, for instance, (Valentine 2008), I use the preposition in to overcome what I see as a hegemonic position implicitly at work in the use of with. To live with someone/something stresses indeed the subjectivity and agency of the person who carries out that act and, under certain conditions, might also suggest that to tolerate them is the only possible way to live with. Using in allows to take into consideration the growing ethno-cultural mixing of contemporary societies without falling into the trap of constructing two opposite, essentialized categories (we/them) and without resorting to the very problematic concept of tolerance (Brown 2009).

${ }^{3}$ Yalla, blog post, 17/05/2013: http://www.yallaitalia.it/2013/05/signore-e-signori-buongiorno-iniziamo-limbarco/

${ }^{4}$ Phrases in dialect are reported in their original formulation, with English translation in parentheses.

${ }^{5}$ Rete G2, forum, 22/03/2008: http://www.secondegenerazioni.it/forum/viewtopic.php?f=7\&t=899
} 
${ }^{6}$ Personal interview with Valentino AG, 19/06/2016.

${ }^{7}$ Available at https://www.youtube.com/watch?v=bu7uUGBntVs

${ }^{8}$ Personal interview with Rosa Jijon, 27/04/2017. For a similar video intervention on national belonging and its contested meaning see "I am an American": Video portraits of unsafe US citizens by Cynthia Weber, available on http://www.youtube.com/user/opendemocracyteam, and the forum discussion in International Political Sociology (vol. 4, issue 1, 2010).

${ }^{9}$ Available at https://www.youtube.com/watch?v=90hEvHmbHYg

${ }^{10}$ Interview available at http://lacittanuova.milano.corriere.it/2013/08/14/prendi-un-bar-di-borgata-gira-un-filmsullitaliano-medio-scopri-genewration/

${ }^{11}$ Personal interview with Amin Nour, 05/09/2015. 